\title{
New Legal Solutions in the Hungarian Criminal Law with Reference to the Fight against the Irregular Migration
}

\author{
Robert Bartko \\ Assoc. Prof. Dr. University of Györ, Faculty of Law and Political Sciences, Department of Criminal Sciencies
}

\section{Abstract}

International migration has intensified during the last two decades. Europe has been receiving increasing number of migrants from the developing countries (primarily from the Near-East). The number of the irregular migrants entered the European Union reached unprecedented levels in the last four years. The mentioned phenomenon affected the European Union and the Member States as well. The irregular migration is defined and managed in different ways by the Member States. In 2015, when Hungary was in the centre of the migratory flow, a political decision on taking the necessary criminal measures to stop the irregular migrants was made by the Hungarian Government. The legal response concerned widely the Hungarian legal system. In the centre of the amendment were the criminal law and the criminal procedure law. Within the frame of the mentioned decision the Hungarian Criminal Code was amended with three new crimes which are the followings: damaging the border barrier, unlawful crossing the border barrier and obstruction of the construction work on border barrier. The above-mentioned amendment modified the general section of the Criminal Code as well concerning the irregular migration. The aim of the paper is to present on the one hand the solution of the Hungarian criminal law with special reference to the new statutory definitions using the analytical method and on the other hand the data of the Hungarian criminal-statistics as well. However, it shall be underlined that in our paper we could work only with the offical criminal-statistics for 2015-2017 because until the finishing of our study the Unified Hungarian Criminal Statistic of the Investigation Authorities and Prosecution did not summarize yet the data concerns the year of 2018 .

Keywords: Hungarian criminal code, irregular migration, crimes concerning the irregular migration in hungary, border barrier, fight against the irregular migration in hungary, crimes against the border barrier in hungary

\section{Introduction}

As a starting point, it shall be underlined that the irregular migrant can be defined as an individual who crosses a border without proper authority or violating conditions for entering a country ${ }^{1}$. The irregular migrants usually use the following ways entering the territory of EU: (a) border-crossing "without proper authority, either through clandestine entry or with fraudulent documents; (b) entering with authorisation, but overstaying it; (c) deliberatly abusing the asylum system; or under the control of the smugglers and traffickers ${ }^{2}$. In connection with the mentioned thoughts, it shall be emphasized that the international migration has intensified during the last two decades ${ }^{3}$. Europe has been receiving increasing number of migrants from the developing countries. Until between 2009 and 2010 the number of the irregular migrants crossed the border of the EU was about 100.000 each year ${ }^{4}$, this number rose to more than 280.000 by 2014 at the pan-European level. The mentioned number represents a $138 \%$ increase over the previous years ${ }^{5}$. It can also be factually recorded that the number of migrants entered the EU irregularly has increased further in the recent past, to an unprecedented level in 2015 and 2016 . According the FRONTEX data the Member States recorded nearly 1.800 .000 illegal border crossings at the peak of the migration

\footnotetext{
${ }^{1}$ Kuschminder, K. et. al. (2015): Irregular Migration routes to Europe and factors influencing migrants' destination choices. Maastricht Graduate School of Governmance, Maastricht p. 10.

2 Uehling, G. (2004): Irregular and Illegal Migration through Ukraine. International Migration. pp. 77-109.

${ }^{3}$ Triandafyllidou, A \& Maroukis, T. (2012): Migrant smuggling: Irregular migration from Asia and Africa to Europe. Springer, p.1.

${ }^{4}$ Morehouse, Christal \& Blomfield Michael (2011): Irregular migration in Europe. Migration Policy Institute, Washington DC, p. 8.

${ }^{5}$ EUROPOL (2016): European Union Terrorism Situation and Trend Report
} 
crisis in 2015, while in 2016 this number - although much less - was 511.047 illegal border crossing which can be considered still extremely high ${ }^{1}$. Based on the data published by the FRONTEX annual reports the European migratory crisis developed in the last 5 years as the followings:

\begin{tabular}{|l|l|l|l|l|}
\hline Year/Route & 2014 & 2015 & 2016 & $2017 / 2018$ \\
\hline Western African & 276 & 874 & 671 & $421 / 1531$ \\
\hline $\begin{array}{l}\text { Western } \\
\text { Mediterranean }\end{array}$ & 7842 & 7164 & 10.231 & $23.143 / 57.034$ \\
\hline $\begin{array}{l}\text { Central } \\
\text { Mediterranean }\end{array}$ & 170.664 & 153.946 & 181.459 & $118.962 / 23.485$ \\
\hline $\begin{array}{l}\text { East } \\
\text { Mediterranean }\end{array}$ & 50.834 & 885.386 & 182.277 & $42.305 / 56.561$ \\
\hline $\begin{array}{l}\text { Circular route from } \\
\text { Albania }\end{array}$ & 8841 & 8932 & 5121 & $6396 / 4550$ \\
\hline Black Sea & 433 & 68 & 1 & $537 / 0$ \\
\hline Western Balkan & 43.357 & 764.038 & 130.261 & $12.178 / 5869$ \\
\hline $\begin{array}{l}\text { Eastern borders } \\
\text { route }\end{array}$ & 1275 & 1920 & 1349 & $776 / 1084$ \\
\hline
\end{tabular}

Table 1.: Detections of illegal border-crossing int he EU between 2014 and 2018 (Source: FRONTEX Annual Rysk Analysis for 2015-2019, https://frontex.europa.eu)

The migration - whether irregular or legal - is not a new phenomenon in Europe, it has presented on the European continent for decades. "Migration has been a natural phenomenon of changes in the world since the formation of mankind, which at times intensifies, becomes explosive, and sometimes eases." 2 In the past decades, a number of serious political and economic changes have taken place in the world. It shall be underlined, that one of its detrimental effects was the uptrend of the migratory pressure. However, at the same time, its nature and method have changed as well. Mass immigration - considering on the one hand the origin of people arriving with the migratory wave, and the other hand their belief in belief, furthermore, the feeling of disappointment for the attitude of the Western states - poses a serious public security risk in the host societies, and unfortunately - as a result of the mentioned facts - it can be seen in criminal statistics as well. In the recent years, the wave of intensive migration pointed out that the European Union's liberal policy pursued by the majority of the European Member States has caused a serious security deficit in Europe. The positive expectations and impacts that have served and serve nowadays as well in many Member States for a permissive immigration policy are becoming unmanageable in the current, uncontrolled migration situation. Irregular migration is accompanied by other forms of crime, including the intensification of human trafficking, and terrorism.

For the above-mentioned facts irregular migration as a phenomenon is defined in different ways by the Member States. The most of them give an administrative legal answer to the problem. However, it can be underlined that the criminalization is not a widespread response, the illegal border crossing and the illegal residence are not considered a criminal offence in the western European countries ${ }^{3}$. Although Europe is still divided on how to consider the irregular migration, in the political dialogue it is often described as a phenomenon which threatens the state sovereignty and the public security. The news reports show that the public security can be influenced by the irregular migration. Therefore, different legal measures have been adopted by many Member States after 2015 in order to control the illegal migration and deal with its harmful consequences 4 .

The irregular migration as a phenomenon is generally defined as an petty offence in the European Union, however, there are other Member States solve the problem on the level of the administrative law. It shall be emphasized that the degree

${ }^{1}$ FRONTEX (2018): Risk Analysis for 2018. p. 8.

2 Mária, Tóthné Demus (2005): Új kihivások a hazánkat érintő illegális migráció kezelésében. Ügyészek Lapja Vol. 3. p. 53.

3 Guild, E. et. al. (2016): Irregular Migration, Trafficking and Smuggling of Human Beeings: Policy Dilemmas in the EU. CEPS Paperback, 22 February 2016. p. 24.

${ }^{4}$ Broaders, Dennis \& Engbersen, Gottfried (2007): The fight against illegal migration. Identification Policies and Immigrants' Counterstrategies. Amercian Behavioral Scientist Vol. 50. Nr. 12. p.1592. 
of de jure criminalisation is limited - in the most Western countries illegal residence as such is not crime ${ }^{1}$. However, the irregular migration is often described as a threat to state sovereignty and to public security ${ }^{2}$. This unfavourable effect was recognized by the Hungarian Government in 2015, therefore a decision on using criminal tools in the fight against the irregular migration was accepted by the Hungarian legislator. In 2015, when Hungary was in the centre of the migratory flow, a political decision on taking the necessary criminal measures to stop the irregular migrants was made by the Hungarian Government and the Parliament. The legal response concerned widely the Hungarian legal system. In the centre of the amendment were the criminal law and the criminal procedure law. Within the frame of the mentioned decision the Hungarian Criminal Code was amended with three new crimes which are the followings: damaging the border barrier, unlawful crossing the border barrier and obstruction of the construction work on border barrier. The aim of the paper is to present on the one hand the Hungarian criminal solution with special reference to the new statutory defintions concerning the irregular migration and to present the mentioned elements of crimes, furthermore on the other hand the data of the Hungarian criminal-statistics as well.

\section{Antecedents of the Hungarian legislation}

The aim of introduction on more effective, legal action against illegal immigration in Hungary has become the subject of political dialogue since the beginning of 2015. Namely, the pressure of irregular migration concerned Hungary has been steadily strengthened from the mentioned year. If we examine only the number of asylum seekers in the 2014-2015 period, it shall be underlined that compared to the approximately 43,000 asylum applications filed in 2014 , this figure rose to 78,000 by July 2015 , and till the end of the 2015 was close to $180,000^{3}$. Only during the month of September 2015 - before the finishing the construction work concerning the fence by the Hungarian-Serbian border - there was a total number of 138.396 migrant entries.

Therefore, the Hungarian Government has defined - as a fundamental security policy goal - the curbing of the influx of illegal immigrants and the creation of legal regulations to achieve it. The first step in achieving this legal policy goal was the decision of the Hungarian Government 1401/2015. In the mentioned decision the Ministry of the Interior had a deadline until 1 July to "prepare for the establishment of about $175 \mathrm{~km}$ long and 4 meter high temporary border fence by the green border at the Serbian-Hungarian border" and, secondly, to prepare of the legal amendments on curbing illegal immigration. After the above-mentioned Government decision, as a second step, the legislator's aim was to ensure the establishment of the closing of border until the substantive and procedural rules of criminal law and criminal procedure enter into force. This aim was meant to serve by the decree of the Hungarian Government 213/2015., which provided for the imposition of an administrative fine on the offenses against the area of the temporary closing of border and its construction ${ }^{4}$.

The construction of the border barrier began in early July 2015, and it was completed by Monday, 14 September 2015. After the first step of the construction works had been finished by the SerbianHungarian border, Hungary started - as a second step - the construction of a second fence along the Croatian-Hungarian border as well 5 .

\footnotetext{
1 Guild, E et. al (2016): ibid p. 24-25.

2 Koser, K. (2005). Irregular migration, state security and human security. GCIM., 2005., p. 10-11.

3 Szilveszter, Póczik (2018): A határzárral kapcsolatos büncselekmények elkövetőinek szociológiai vizsgálata a Csongrád megyei büntetőeljárások alapján. Kriminológiai Tanulmányok Vol. 55. p. 11.

4 The scope of these practices is set out in Sections 2-3 of the decree: (a) entry into the area of the temporary closing of border during its construction and maintenance; (b) obstructing construction work in any form; (c) introducing a drone or other unmanned remote control device into the construction site; (d) obstructing the access of persons working in the area of the closing of border; (e) obstructing the access of vehicles and means of transport to the area affected by the construction of the boundary lock. According to the decree, these actions were punishable by a fine of HUF 50,000-300,000, as the case may be. As the system came to a standstill on 15 September 2015 and the Act CXL of 2015 came into force that mentioned regulation was repealed by the Hungarian Government.

${ }^{5} \mathrm{An}$ interesting data that after Hungary closed the Hungarian-Serbian border with the border barrier the number of the irregular migrants entered Hungary decreased to only 315 in November and to 270 in December 2015.
} 
After these above-mentioned antecedents, Act CXL of 2015 was adopted by the Hungarian Parliament on 04 September 2015. This Act has introduced significant changes in several areas of the Hungarian law from 15 September 2015. The reason of the amendments had several directions. On the one hand, logistical and other social tasks related to immigrants crossing the borders of Hungary were a significant economic burden for the country, which had to be remedied. On the other hand, the protection of state sovereignty has been formulated as a legal policy goal, which means is the development of a definite border protection policy, and the widening of the state's self-defense function, which - according to the Hungarian Government's opinion -, is partly possible by installing and building defense equipment. Thirdly, the need for action against the accompanying phenomena concerning the irregular migration - for example: trafficking in human beings or terrorism -, has also justified the adoption of the abovementioned legislation. To ensure the border security by preventing asylum seekers and immigrants from entering and enabling the option to enter through official points and claim asylum in Hungary in accordance the Hungarian, and the European law was also a policy goal of the Hungarian Government.

One of the important elements of the defense system, known as the "physical and legal boundary lock", was the development of criminal law solutions to the problem. The criminal reform introduced to curb illegal migration has had two pillars, one on criminal law and one on criminal procedural law. The essence of the former is partly the creation of new sui generis statutory definitions in the Hungarian Criminal Code with reference to the border barrier. Furthermore to ensure that criminal procedures in connection with the referred crimes can be finished rapidly, the Hungarian Act on Criminal Procedure ${ }^{1}$ was amended as well. A new procedural legal frame was inserted into the Chapter titled „Special criminal procedures". In this chapter many special procedural rules are regulated by the legislator, where the reason of the special regulations is either the special character of the defendant, or the special character of the concrete criminal case. In connection with our paper the latter one is of importance. Namely, the mentioned special rules can be applied only for the sake of the crimes against the border barrier. Creating of the new special procedural rules enabled for the authorities to conduct the procedure started because of a crime against the border barrier very rapidly. Although the amendments concerned the General Part of the Hungarian Criminal Code as well, in our paper we deal only with the new statutory definitions mentioned above.

\section{The new crimes concerning the irregular migration in the Hungarian Criminal Code}

After the mentioned antecedents three new crimes has been inserted by the Act CXL of 2015 into the Hungarian Criminal Code (Act C of 2012): unlawful crossing of the border barrier (Sec. 352/A.), damaging the border barrier (Sec. 352/B.), and the obstruction of the construction work on the border barrier (Sec. 352/C.).

According to the Section 325/A of the Hungarian Criminal Code any person who enters unlawful the territory of Hungary across the border barrier commits the crime titled the unlawful crossing of the border barrier. The mentioned crime can be considered as a "delictum commune", therefore its perpetrator can be anyone. However, if we look at the reason of creation this statutory defintion, it is quite clear that the Hungarian legislator drafted it specifically in order to curb the irregular migration. The mentioned fact is confirmed by the Hungarian criminal-statistic as well because the most of the perpetrators had the following nationality: Afghan, Iraqui, Syrian, Pakistani, Iranian and Kosovo². In this context, several scientific articles $^{3}$ have dealt with the accordance between the Hungarian regulation and the provision of Article 31 Par. (1) of the

\footnotetext{
1 The mentioned amendment connected to the former Act on Criminal Procedure (Act XIX of 1998 Chapter XXVI/A.), but the special criminal procedural regulation has been kept by the legislator in the system of the new Act on Criminal Procedure as well (Act XC of 2017 Chapter CVII.).

2 Based on the data of the Unified Hungarian Criminal Statistic of the Investigation Authorities and Prosecution

3 In the mentioned topic in the Hungarian literature see: Zoltán, Hautzinger (2018): A migráció és a külföldiek büntetőjogi megjelenése. AndAnn, Pécs pp. 152-158.; Judit, Tóth (2015): „... a hazájukat elhagyni kényszerülők emberi jogainak és alapvető szabadságainak védelmére. Fundamentum Vol. 19. Nbr. 4. pp. 63-64.; Zsolt, Kopasz (2018): Ügyészségi tapasztalatok az államhatár rendjét érintő büncselekményekkel összefüggő büntetőeljárásokról. Kriminológiai Tanulmányok Vol. 55. p. 37., Anna Terézia, Bartos (2017): A határzár tiltott átlépésének megítélése a joggyakorlatban. Pécsi Határör. Tudományos Közlemények 19. szám, pp. 314-315.; Norbert, Tóth (2016): „Államarcú” nemzetközi jog, avagy a 2015 őszén módosított magyar Büntető Törvénykönyv a menekültek jogállásáról szóló
} 
Geneva Convention and its Protocol. According to the mentioned regulation of the Geneva Convention: „the contracting states shall not impose penalties, on account of illegal entry or presence, on refugees who coming directly from the territory where there life or freedom was threatened in the sense of article 1, enter or are present in there territory wihtout authorization, provided they present themselves without delay to the authorities and show good cause for their illegal entry or presence"1. However, in this context hereby we shall cite the provision of the Article XIV Par. (4) of the Hungarian Constitution: „any person has not Hungarian citizenship arrived in Hungary through a country where he was not exposed to the persecution or its direct threat is not entitled to asylum".

The correct interpretation of the Convention and its mentioned Protocol with respect to the crimes against the border barrier - especially to the unlawful crossing of the border barrier - is also interesting because in a significant number of criminal cases the defense has been argued before the court with the permission of the law as ground for the preclusion of the punishability. However, the mentioned argument was refused by the courts. Namely, the mentioned argument could have been used before the court in case of existence of the following conditions: (a) the fact of the unlawful border-crossing; (b) the direct geographical link between the State affected by the unlawful entry and the State of persecution; (c) immediate application to the authorities; (d) the consistency of the grounds for unlawful entry with the values to be protected by the Convention; (e) the fact of refugee status. First of all, we would like to point out that the fundamental right to refugee status, which would result in a kind of automatism in asylum procedures, cannot be deduced from the text of the Convention and its mentioned Protocol. For this reason, we disagree with the view expressed in the Hungarian literature ${ }^{2}$ that the fact of refugee status precedes the formal decision of the authority concerning it and therefore, it is very problematic to accuse these persons with the mentioned crime. Such an interpretation would make the asylum procedure completely formal, without giving it any discretion in deciding on the application. However, if such a person immediately applies to the authorities and submits his application, the decision on his refugee status is considered as a preliminary question in the criminal procedure, which must precede the judicial decision of the criminal proceedings. However, it shall be emphasized that based on the mentioned article of the Hungarian Constitution and the Hungarian Act on Asylum (Act LXXX of 2007) Hungary has continuously developed the so-called "safe third state concept"3. According to the Decree 191/2015 of the Hungarian Government that states from which the migrants can entry directly the territory of Hungary can be considered as a safe country. Therefore, the above-mentioned principle on "condition of directness" which is relevant for the application of the Geneva Convention and its mentioned Protocol, is not applicable concerning that defendants who are accused with a crime against the border barrier. That is why we agree with Norbert Tóth's view ${ }^{4}$ that the condition of directness should be used in geographical meaning for the application of the mentioned conventional provision. On the basis of the above mentioned facts, it can be stated that it is not permissible in itself to create statutory definitions for the protection of border barrier and to treat them under special

1951. évi genfi egyezmény 31. Cikk (1) bekezdése fényében. In. Zoltán, Hautzinger (edit.): A migráció bűnügyi hatásai. Magyar Rendészettudományi Társaság Migrációs Tagozat, Budapest, pp. 240-243.; The overall of Hungarian Helsinki Committee (16 September 2015): https:/www.helsinki.hu/az-1951-evi-genfi-egyezmeny-31-1-cikkenek-alkalmazasarol/.

${ }_{1}^{1}$ Article 31. Par. (1) of the Geneva Convention (1951) and Protocol (1967) Relating to the Status of Refugees

2 Anna Terézia, Bartos (2017): ibid p.314.

${ }^{3}$ Kjaerum, Morten (1992): The Concept of Country of First Asylum. International Journal of Refugee Law. Vol. 4. Nbr. 4., pp. 513-514.

${ }^{4}$ Norbert, Tóth (2016): ibid. p. 242. 
procedural rules, however, the legislator has to take into account that cases where the defendant has applied for refugee status under the criminal procedure1.

In the following table we summarize the registered unlawful crossings of the border barrier based on the unified Hungarian criminal statistic mentioned above:

\begin{tabular}{|l|l|l|l|}
\hline & $\mathbf{2 0 1 5}$ & $\mathbf{2 0 1 6}$ & $\mathbf{2 0 1 7}$ \\
\hline $\begin{array}{l}\text { unlawful crossing of border } \\
\text { barrier (Sec. 352/A. of the } \\
\text { Hungarian Criminal Code) }\end{array}$ & 914 & 2843 & 22 \\
\hline
\end{tabular}

Table 2: The detected unlawful crossings of border barrier in Hungary between 2015 and 2017 (Source: the Unified Hungarian Criminal Statistic of the Investigation Authorities and Prosecution)

According to the Sec. 352/B. of the Hungarian Criminal Code any person who damages or destroys the border barrier and its devices commits the damaging of the border barrier, insofar as the act did not result in a more serious criminal offence. Following the mentioned definition it shall be underlined that this crime can be considered as a subsidiary statutory definition. The legal object protected by the legislator is not only the territorial integrity of Hungary, but also the protection of the border barrier as well. The reason of creating the mentioned crime is that it is required to punish that perpetrator who endangers with his conduct the protection function of the border barrier built by the state 2 . Nevertheless, it shall be emphasized that the border barrier built in 2015 at the Serbian-Hungarian and the Croatian-Hungarian border is protected not only by the above-mentioned statutory definition, but also by the crime regulated under the Sec. 352/C of the Hungarian Criminal Code. According to the mentioned Section any person who obstructs the construction or the maintaining work of the border barrier commits a crime titled obstruction of construction work on the border barrier. This crime is also a subsidiary statutory definition, because the perpetrator can be punished for this crime only that case if the act committed by the perpetrator did not result in a more serious criminal offence. Any conduct by which the perpetrator can obstruct the works on the border closure may constitute according to the mentioned Section ${ }^{3}$. In the past few years the crime titled damaging of border barrier occurred in the judicial practice, however, the obstruction of construction works on border barrier is not. In the following table we summarize the relevant data of the Hungarian criminal statistic according to the mentioned two criminal offences:

\begin{tabular}{|l|l|l|l|}
\hline & $\mathbf{2 0 1 5}$ & $\mathbf{2 0 1 6}$ & $\mathbf{2 0 1 7}$ \\
\hline $\begin{array}{l}\text { damaging of border barrier } \\
\text { (Sec. 352/B. of the } \\
\text { Hungarian Criminal Code) }\end{array}$ & 22 & 1543 & 863 \\
\hline
\end{tabular}

\footnotetext{
1 It should be noted that in most of the criminal proceedings conducted in Hungary due to unlawful crossing of border barrier, the defendants entered the territory of the country in violation of the border barrier, furthermore, they did not register with the authorities without delay, and in many cases - as the country of destination was not our country - they did not apply for asylum. It shall be underlined that the mentioned conditions without examining exclude the applicability of Article 31 of the Geneva Convention and its Protocol.

2 Zoltán, Hautzinger: Büntetőjogi tényállások a külföldiség és a migráció vonzásában. In. Zoltán, Hautzinger (edit.): A migráció bűnügyi hatásai. Magyar Rendészettudományi Társaság Migrációs Tagozat, Budapest, pp. 191-192.

3 Sándor, Madai: „A tömeges bevándorlás okozta válsághelyzet” kezelésének büntető anyagi jogi eszközei hazánkban. In. Zoltán, Hautzinger (edit.): A migráció bűnügyi hatásai. Magyar Rendészettudományi Társaság Migrációs Tagozat, Budapest, p. 253.
} 


\begin{tabular}{|l|l|l|l|}
\hline Obstruction of construction & 0 & 0 & 0 \\
work on border barrier & & & \\
(Sec. 352/C. of the & & & \\
Hungarian Criminal Code) & & & \\
\hline
\end{tabular}

Table 3: Registered crimes concerning the damaging of border barrier and obstruction of construction work on border barrier in Hungary between 2015 and 2017 (Source: the Unified Hungarian Criminal Statistic of the Investigation Authorities and Prosecution)

Common characteristics of the above-mentioned crimes against the border barrier that each crime can be committed only with intent. Furthermore, several qualified cases were linked by the legislator to the statutory definition of damaging of border barrier and to the unlawful crossing of border barrier. These are the followings: perpetration by displaying a deadly weapon, or by carrying a deadly weapon, and perpetration as a member of a mass riot. The most serious qualified case by the both above-mentioned crimes is if the perpetration results in death. If the defendant is sentenced for a crime against the border barrier for fixed-term imprisonment, according to the Sec. 60. Par. (2a) of the Hungarian Criminal Code, the defendant shall be expelled from the territory of Hungary. Namely, in the mentioned cases the application of expulsion is compulsory'.

\section{Final Remarks}

Based on the data already described above, it can be clearly seen that due to obstruction of construction work on border barrier regulated under the Sec. 352/C. of the Hungarian Criminal Code, no criminal proceedings were conducted. This in itself calls into question the legitimacy of the existence of the mentioned statutory definition. Nevertheless, there has been a massive decrease in cases of the other crimes against the border barrier in recent times as well. In 2015 the number of the registered unlawful crossings of border barrier was 914, in 20162843 , and in 2017 - due to the changings in connection with the migration routes - was already only 22 . The same tendency can be seen with regard to the crime damaging of border barrier as well. Namely, in 2015 the number of this criminal cases was 22, in 2016 1543, and in 2017 "only" 863. However, the number of cases is not the same as the number of criminal procedures conducted due to the mentioned crimes. An interesting data that in 2017 the authorities have already taken action against only 20 defendants in only 10 criminal procedures ${ }^{2}$. These data show that the political decision on building the border barrier made by the Hungarian Government in 2015 was well-founded because it resulted on the one hand the relief of the migratory pressure and the cease of the chaotic situations made by the migratory flow in Hungary in 2015, and the other hand the changing of the Western-Balkanian migratory route. The fact mentioned latter is confirmed by the reports concerning from the year of 2015 till 2018 announced by the FRONTEX which underline that the migratory pressure decreased in the WesternBalkanian migratory route. If we look at the data with regard the mentioned route we can see the significant changings. Until in 2015 - before the finishing of the construction works on the border barrier at the Serbian-Hungarian, and at the Croatian-Hungarian border - a number of 764.038

\footnotetext{
${ }^{1}$ Nevertheless, someone who has been granted asylum in Hungary, according to the Sec. 59. Par. (2) of the Hungarian Criminal Code, can not expel from the territory of Hungary, therefore in that criminal procedures which object is an crime against the border barrier, the court shall take into account if the defendant was granted asylum.

${ }^{2}$ The mentioned data is based on the Unified Hungarian Criminal Statistic of the Investigation Authorities and Prosecution
} 
migrants entered the territory of EU - and the Central-European countries -, from the year of 2016 a continuous decline can be experienced regarding to the mentioned route. In 2017 only a number of 12.178, in 2018 only a number of 5869 migrants tried to enter unlawful the EU. In this context, the Hungarian solution is not objectionable with regard to the international and European commitments of Hungary, and its results are undisputed. Although Hungary has suffered many political attacks due to the border barrier built in 2015, from the aspect of the international, European, and the constitutional law the Hungarian solution is not objectionable. Of course, the amendment of the Hungarian Criminal Code, and the new statutory definitions created by the legislator can be criticized from dogmatically aspects, however, we are sure that the necessary modifications will be adopted by the Hungarian legislator in the near future. For example, - among others - the repeal of the statutory definition on obstruction of construction work on border barrier shall be considered by the legislator with regard to the fact that no criminal procedure was conducted by the authorities due to the mentioned crime between 2015 and 2018. In summary, therefore, according to our opinion it is not a refugee law question, but also a task has to be solved by the internal criminal law. Hungary is a state of rule of law and we can be sure that - apart from the political aim to protect the sovereignty of Hungary - Hungary will work together with the European institutions towards a more efficient and fairer European migration and asylum policy.

\section{Bibliography}

[1] Anna Terézia, Bartos (2017): A határzár tiltott átlépésének megitélése a joggyakorlatban. Pécsi Határőr. Tudományos Közlemények 19. szám

[2] Broaders, Dennis \& Engbersen, Gottfried (2007): The fight against illegal migration. Identification Policies and Immigrants' Counterstrategies. Amercian Behavioral Scientist Vol. 50. Nr. 12.

[3] EUROPOL (2016): European Union Terrorism Situation and Trend Report

[4] FRONTEX (2018): Risk Analysis for 2015-2019

[5] Guild, E. et. al. (2016): Irregular Migration, Trafficking and Smuggling of Human Beeings: Policy Dilemmas in the EU. CEPS Paperback, 22 February 2016.

[6] Judit, Tóth (2015): „... a hazájukat elhagyni kényszerülők emberi jogainak és alapvető szabadságainak védelmére. Fundamentum Vol. 19. Nbr. 4.

[7] Kjaerum, Morten (1992): The Concept of Country of First Asylum. International Journal of Refugee Law. Vol. 4. Nbr. 4.

[8] Koser, K. (2005). Irregular migration, state security and human security. GCIM., 2005.

[9] Kuschminder, K. et. al. (2015): Irregular Migration routes to Europe and factors influencing migrants' destination choices. Maastricht Graduate School of Governmance, Maastricht

[10] Mária, Tóthné Demus (2005): Új kihívások a hazánkat érintő illegális migráció kezelésében. Ügyészek Lapja Vol. 3.

[11] Morehouse, Christal \& Blomfield Michael (2011): Irregular migration in Europe. Migration Policy Institute, Washington DC

[12] Norbert, Tóth (2016): „Államarcú” nemzetközi jog, avagy a 2015 őszén módositott magyar Büntető Törvénykönyv a menekültek jogállásáról szóló 1951. évi genfi egyezmény 31. Cikk (1) bekezdése fényében. In. Zoltán, Hautzinger (edit.): A migráció bünügyi hatásai. Magyar Rendészettudományi Társaság Migrációs Tagozat, Budapest

[13] Sándor, Madai: „A tömeges bevándorlás okozta válsághelyzet” kezelésének büntető anyagi jogi eszközei hazánkban. In. Zoltán, Hautzinger (edit.): A migráció bünügyi hatásai. Magyar Rendészettudományi Társaság Migrációs Tagozat, Budapest

[14] Szilveszter, Póczik (2018): A határzárral kapcsolatos bűncselekmények elkövetőinek szociológiai vizsgálata a Csongrád megyei büntetőeljárások alapján. Kriminológiai Tanulmányok Vol. 55. 
[15] Triandafyllidou, A \& Maroukis, T. (2012): Migrant smuggling: Irregular migration from Asia and Africa to Europe. Springer

[16] Uehling, G. (2004): Irregular and Illegal Migration through Ukraine. International Migration.

[17] Zoltán, Hautzinger (2018): A migráció és a külföldiek büntetőjogi megjelenése. AndAnn, Pécs

[18] Zoltán, Hautzinger: Büntetőjogi tényállások a külföldiség és a migráció vonzásában. In. Zoltán, Hautzinger (edit.): A migráció bünügyi hatásai. Magyar Rendészettudományi Társaság Migrációs Tagozat, Budapest

[19] Zsolt, Kopasz (2018): Ügyészségi tapasztalatok az államhatár rendjét érintő bűncselekményekkel összefüggő büntetőeljárásokról. Kriminológiai Tanulmányok Vol. 55. 